\title{
Trauma-associated bleeding from the bilateral internal iliac arteries resolved using angiographic embolization
}

\author{
Ali Aygün, M.D., ${ }^{1}$ Yunus Karaca, M.D., ${ }^{2}$ Emin Ayan, M.D., ${ }^{3}$ Türkmen Suha, M.D., ${ }^{1}$ Hasan Dinç, M.D. ${ }^{3}$ \\ ${ }^{1}$ Department of Emergency Medicine, Karadeniz Technical University Faculty of Medicine, Trabzon \\ ${ }^{2}$ Department of Emergency Medicine, Kanuni State Hospital, Trabzon \\ ${ }^{3}$ Department of Radiology, Karadeniz Technical University Faculty of Medicine, Trabzon
}

\begin{abstract}
Pelvic fracture is associated with high mortality. The management of major pelvic injuries remains one of the most important issues in modern trauma care. A 39-year-old male patient presented at the emergency department after being hit with a $500 \mathrm{~kg}$ load. His general condition was average with unstable vital signs. Pelvic tomography revealed fractured bone structure, thickening secondary to hematoma in both iliopsoas muscles, and hemorrhage-related active extravasation in the left internal iliac trace. The patient's hemodynamics worsened despite fluid and blood replacement, and angiographic embolization was scheduled. Bilateral embolization of the iliac artery was performed. Control angiography confirmed that full embolization was established. The patient was monitored in intensive care, but expired after three days due to acute kidney failure, disseminated intravascular coagulation, and multi-organ failure. Angiographic embolization is a technique improves hemorrhage control in pelvic trauma but can also increase risk of complications such as ischemia and necrosis.
\end{abstract}

Key words: Angiography; embolization; bilateral internal iliac artery; hemorrhage; trauma.

\section{INTRODUCTION}

Pelvic factures are associated with high mortality. Extensive fractures may cause injury to the surrounding blood vessels, nerves, and urogenital and gastrointestinal organs. Post-traumatic arterial injuries generally result in the demise of the patient prior to arrival at the hospital. The management of major pelvic injuries remains one of the most important challenges in modern trauma care. ${ }^{[l]}$ This report describes a case of bilateral internal iliac artery injury subsequent to pelvic fracture caused by trauma and bleeding in a patient undergoing hemodynamic stabilization using angiographic embolization.

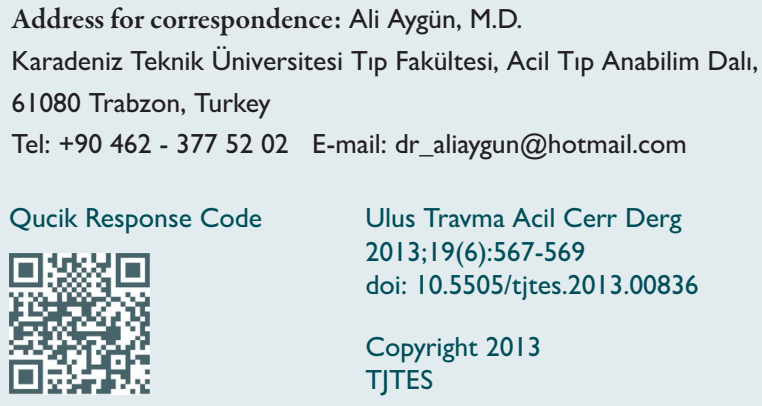

\section{CASE REPORT}

A 39-year-old male patient presented at the emergency department after a 500-kg load fell on him. The patient was lucid and his general condition was rated as average. Blood pressure was $80 / 50 \mathrm{mmHg}$, pulse $120 / \mathrm{min}$ and respiratory rate $22 / \mathrm{min}$. Physical examination revealed sensitivity in the pelvic region, ecchymosis in the scrotum, and deformity and sensitivity in the right femur. Pelvic radiography indicated a displaced fracture of the right femoral shaft, fracture of the bilateral iliac wings, separation of both sacroiliac joints, separation of the symphysis pubis, and a displaced fracture in both the left superior and inferior pubic ramus (Figure la). Following abdominal CT, we observed a linear displacement fracture in the right and left iliac wings, a fragmented displacement fracture extending to the sacroiliac joint in both sacral areas, linear displaced fracture in the left inferior and superior pubic ramus, increased symphysis in the pubis joint space, thickening secondary to hematoma in both iliopsoas muscles, and active extravasation in the left internal iliac artery trace (Figure Ib). Skin traction was applied to the right femur fracture and a pelvic bandage was applied for pelvic stabilization. The patient had shock-related hemodynamic impairment and was intubated and sent to the interventional radiology department. Angiography revealed active extravasation in the bilateral iliac artery truncus. The bilateral iliac artery was embolized us- 

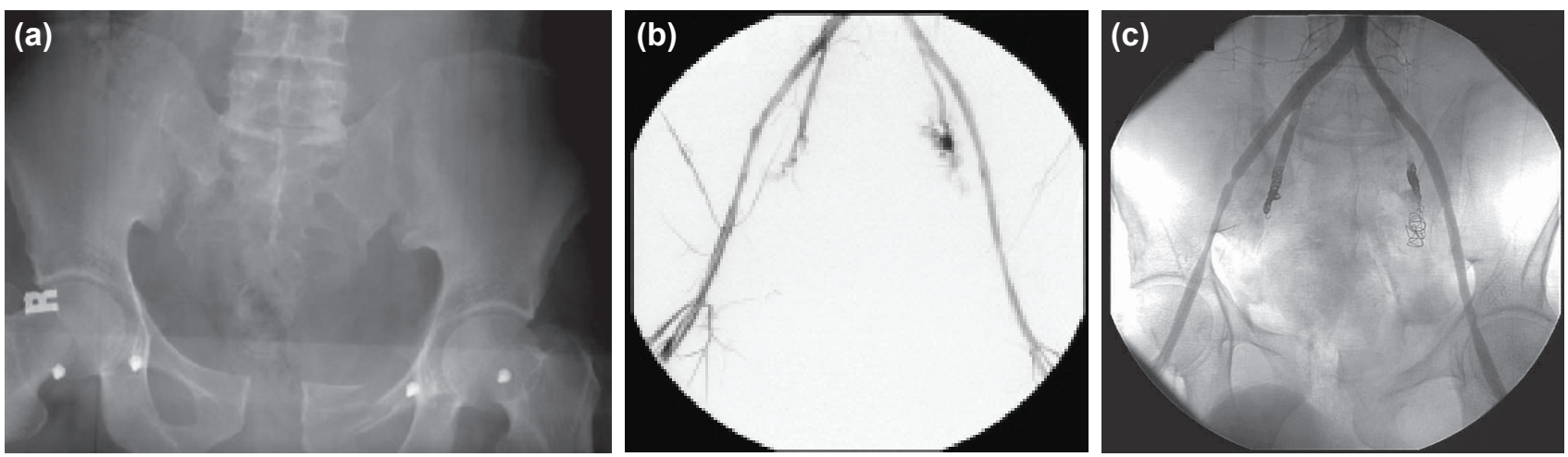

Figure 1. (a) Pelvic radiogram. (b) Active extravasation of contrast material administered by catheterization of the distal abdominal aorta from both internal iliac arteries (before embolization). (c) Appearance of the injury after embolization of the right and left iliac arteries.

ing a combination of NBCA-lipidol mixture and a coil artery occluder device (Figure IC). Control angiography confirmed that full embolization had been established. Following the procedure, the patient was transferred to the intensive care unit for monitoring. Ischemia and gangrenous changes developed in the scrotal and gluteal regions. The patient expired on the third day as a result of acute kidney failure, disseminated intravascular coagulation, and multi-organ failure.

\section{DISCUSSION}

Hemorrhaging in pelvic fractures is largely retroperitoneal leakage from the bone surfaces and the small vessels. Major arterial bleeding occurs in approximately $20 \%$ of cases. [2] Angiography is useful for the diagnosis and treatment of arterial bleeding subsequent to fracture injury. Ligation of the internal iliac arteries is an essential component in the treatment of unstable patients with massive pelvic bleeding. ${ }^{[1]}$ Costantini et al. ${ }^{[3]}$ identified active arterial extravasation in I8 of 31 patients with pelvic fracture who underwent angiography. Although negative angiography findings were obtained in the remaining 13 patients, therapeutic embolization was impossible in four cases due to the presence of hematoma in the fracture. In the present case, active arterial extravasation was identified and the embolization procedure was successfully performed.

Early fracture stabilization and early angiography with embolization, and peritoneal pelvic packing can be performed in hemodynamically unstable patients with pelvic fractures. Angiography performs both diagnostic and therapeutic functions. It may be applied as a primary treatment in patients with serious and complex injuries. Intervention with angiography and embolization in patients with multiple bleeding foci avoids the potential side effects of laparotomy. In addition, arterial hemorrhage control prior to laparotomy prevents the aggravation of bleeding during laparotomy due to the decreasing tamponade effect. Angio-embolization has a success rate of $85-100 \%$ when conducted by experienced medical personnel. ${ }^{[4]}$

Internal iliac artery ligation increases the risk of ischemic complication in both the acute phase and during long-term follow up. Travis et al. ${ }^{[5]}$ reported no significant difference in the incidence of skin necrosis, pelvic perineal infection, and nerve damage in the first 30 days in patients who underwent embolization compared to those who did not. However, a high incidence of hip and perineal region paresthesia was reported among the embolization patients. In a separate study by DuBose et al., no ischemic sequelae were observed during the course of hospitalization among patients who underwent iliac artery ligation. ${ }^{\left[{ }^{I]}\right.}$ In the present case, ischemic and gangrenous changes were observed in the scrotal and gluteal regions following angiographic embolization. The patient expired as a result of acute kidney failure and multiorgan failure on the third post-procedural day. In a study by Karadimas et al. ${ }^{[6]}$ of patients undergoing angiographic embolization, five patients expired in the first $24 \mathrm{~h}$ due to hypotension and hemorrhage two as a result of multi-organ trauma, while one patient succumbed to pulmonary injury and another to multiple organ failure within days of the procedure. In a study by DuBose et al., 18 patients undergoing bilateral internal iliac ligation died. Seven of these patients died as a result of severe head trauma, another six died of cardiac arrest during surgery and five as a result of septic complications. ${ }^{[1]}$

\section{Conclusion}

While angiographic embolization is a powerful technique for suppressing bleeding in pelvic trauma, it is associated with serious complications including ischemic necrosis.

Conflict of interest: None declared.

\section{REFERENCES}

1. DuBose J, Inaba K, Barmparas G, Teixeira PG, Schnüriger B, Talving $\mathrm{P}$, et al. Bilateral internal iliac artery ligation as a damage control approach in massive retroperitoneal bleeding after pelvic fracture. J Trauma 2010;69:1507-14. [CrossRef]

2. Star AJ, Malekzadeh AS. Fractures of the pelvic ring. In: Bucholz RW, Heckman JD, Court-Brown CM, editors. Rockwood \& Green's fractures in adults. Volume 2, 6th ed. Philadelphia: Lippincott Williams \& 
Wilkins; 2006. p. 1585-663.

3. Costantini TW, Bosarge PL, Fortlage D, Bansal V, Coimbra R. Arterial embolization for pelvic fractures after blunt trauma: are we all talk? Am J Surg 2010;200:752-8. [CrossRef]

4. Fang JF, Shih LY, Wong YC, Lin BC, Hsu YP. Angioembolization and laparotomy for patients with concomitant pelvic arterial hemorrhage and blunt abdominal trauma. Langenbecks Arch Surg 2011;396:243-50.
5. Travis T, Monsky WL, London J, Danielson M, Brock J, Wegelin J, et al. Evaluation of short-term and long-term complications after emergent internal iliac artery embolization in patients with pelvic trauma. J Vasc Interv Radiol 2008;19:840-7. [CrossRef]

6. Karadimas EJ, Nicolson T, Kakagia DD, Matthews SJ, Richards PJ, Giannoudis PV. Angiographic embolisation of pelvic ring injuries. Treatment algorithm and review of the literature. Int Orthop 2011;35:1381-90.

\section{OLGU SUNUMU - ÖZET}

\section{Travma sonucu oluşmuş bilateral internal iliyak arter kanamasının anjiyografik embolizasyon ile sonlandırılması \\ Dr. Ali Aygün, ${ }^{1}$ Dr. Yunus Karaca, ${ }^{2}$ Dr. Emin Ayan, ${ }^{3}$ Dr. Türkmen Suha, ${ }^{1}$ Dr. Hasan Dinç ${ }^{3}$}

${ }^{1}$ Karadeniz Teknik Üniverstesi Tıp Fakültesi, Acil Tıp Anabilim Dalı, Trabzon

${ }^{2}$ Kanuni Eğitim Araştırma Hastanesi, Acil Tıp Servisi, Trabzon

${ }^{3}$ Karadeniz Teknik Üniverstesi Tıp Fakültesi, Radyoloji Anabilim Dalı, Trabzon

Pelvis kırıkları mortalitesi yüksek tarvmalardır. Majör pelvis yaralanmalarının yönetimi halen modern travma bakımının en önemli sorunlarından biridir. Otuz dokuz yaşında erkek hasta yaklaşık 500 kg ağılığındaki yükün üzerine düşmesi nedeniyle acil servise getirildi. Hastanın genel durumu orta, vital bulguları dengesizdi. Pelvis tomografisinde kemik yapılarda kırıklar ile her iki iliopsoas kasında hematoma bağlı kalınlaşma ve sol internal iliak trasesinde kanamaya ait aktif ekstravazasyon vardı. Mayi ve kan replasmanına rağmen hemodinamisi bozulan hastaya anjiyografik embolizasyon uygulandı. Hastaya iki taraflı iliak arter embolizasyonu yapıldı. Embolizasyon sonrası yapılan kontrol anjiyografide tam embolizasyon sağlandığı görüldü. Hasta yoğun bakımında takibe alındı. Hasta takibinin üçüncü gününde akut böbrek yetersizliği ve dissemine intravasküler koagülasyon ve çoklu organ yetersizliği nedeniyle kaybedildi. Pelvik travmada anjiyografik embolizasyon kanama kontrolü açısından başrilı sonuçlar alınan bir yöntem olup iskemi nekroz gibi ciddi komlikasyonları beraberinde getirebilir.

Anahtar sözcükler: Anjiyografi; embolizasyon; iki taraflı internal iliak arter, kanama, travma.

Ulus Travma Acil Cerr Derg 2013;19(6):567-569 doi: 10.5505/tjtes.2013.00836 